\title{
Selected functional properties of oxo-degradable materials containing antimicrobial substances
}

\author{
Edyta Gibas ${ }^{1}$, Agnieszka Richert ${ }^{2 *}$ \\ Institute for Engineering of Polymer Materials and Dyes, M. Skłodowskiej-Curie 55 Street, 87-100 Toruń, Poland \\ ${ }^{1}$ Branch of Paint and Plastics, Chorzowska 50A Street, 44-100 Gliwice, Poland \\ ${ }^{2}$ Branch of Processing of Polymer Materials, M. Skłodowskiej-Curie 55 Street, 87-100 Toruń, Poland \\ "Corresponding author: e-mail: a.richert@impib.pl
}

\begin{abstract}
Polyethylene oxo-degradable composites containing antibacterial substances in the form of vegetable oils: geranium, clove and eucalyptus as well as a mixture of nanoAg with nanoCu were discussed. Antibacterial film: PE-0, PE1A, PE-2B, PE-3C, PE-4D properties were verified according to ISO 22196:2011 "Measurement of antibacterial activity on plastic and other non-porous surfaces" for the two standard bacteria species of $E$. coli and $S$. aureus, whereas water vapour permeability tests (Pv) were carried out acc. ISO 15106-2007 "Plastics. Foils and plates. Determination of water vapor transmission rate. Part 1: Humidity sensor method". Film marked PE-4D showed the best antibacterial features and good barrier properties.
\end{abstract}

Keywords: polymeric composites, antibacterial properties, essential oils, nanoAg-Cu, permeability of water vapour.

\section{INTRODUCTION}

In the past 40 years, polyethylene (PE) has been one of the most commonly produced polyolefines in the world. It is resistant to the elements, as opposed to oxo-degradable polyethylene, which can be disintegrated in the natural environment by microorganisms over a period of a few weeks ${ }^{1,2,3,4}$. Oxo-degradable polyolefines are activated by metal salts with variable valencies, which increase the polymer's capabilities to disintegrate under light and oxygen exposure by catalysing the oxidising degradation of the polymer chain. Polyolefines can be produced by means of the same equipment as that used for conventional materials. Furthermore, they demonstrate the same physical and chemical properties as the standard material. The additional benefit they offer is their ability to decompose without emitting carbon dioxide, which is very important from an ecological point of view ${ }^{5,6,7,8}$.

The environmental hazards posed by the production and use of polymer materials has led researchers to search for new technologies for the production and use of products. Different active substances can be introduced into polymeric materials, including substances known to destroy bacteria. Polymeric antibacterial materials are created by combining conventional polymer plastic with antibacterial additives, which inhibit the growth and proliferation of bacteria. Such materials increase the range of application of polymers in the packaging industry, 9 .

The discussion about antibacterial or biostatic substances requires explaining the concepts of antibacterial activity and effectiveness. Antibacterial activity assumes a specific numeric value. It constitutes the difference in logarithms between the number of living bacterial cells detected in a product (e.g. film) containing an antibacterial substance and those present in one without such an addition. In turn, antibacterial effectiveness is the capability of an antibacterial substance to inhibit the development of bacteria on the surface of a polymeric material containing an antibacterial substance. Antibacterial effectiveness is determined by antibacterial activity.
The condition for ensuring the right resistance of polymeric materials against microorganisms is to ensure diffusion of the active substance over the surface of the product. Natural essential oils are used more and more often in the processing of polymeric materials. They can be obtained via water distillation using stalks, leaves, inflorescence, infrutescence or roots. The oils vary in content depending on the plant species as well as the climatic and soil conditions in which the plant vegetates ${ }^{\mathbf{1 0}}$. Essential oils and nano-compounds have gained the interest of research centres conducting studies on the application of biocidal substances in polymeric materials, as they constitute a certain alternative to antibiotics or bacteriocines.

Additives in the form of organic and inorganic compounds are intended to change the functional properties of paints and varnishes. They can also be used in medical applications ${ }^{11,12,13,14,15,16}$ and in the processing of polymeric materials ${ }^{11,17,18}$.

The objective of the study was to obtain oxo-degradable films with at least bacteriostatic properties. Modification of polyethylene using oils and nano ingredients can be an interesting alternative to traditional antibacterial substances, mainly antibiotics, bateriocines and polyhexamethylene guanidines $(\mathrm{PHMG})^{\mathbf{1 9}, \mathbf{2 0}, 21,22}$. The article is a continuation of work on polymeric materials containing antibacterial and bacteriostatic substances.

\section{MATERIAL AND METHODS}

\section{Material}

Films extruded from PE-LD Malen E GGNX 18-D003 (Lyondell Basell) polyethylene (reference material; symbol PE-0) and polyethylene containing $1 \mathrm{wt} \%$ of an oxo-degradable concentrate and antibacterial substances were studied. These substances consisted of the following essential oils: geranium, clove, eucalyptus (ETJA S.C., Poland) (1 wt \%) as well as a nanoAg and nanoCu mixture (commercially available masterbatch on a polyethylene support; particle diameter: $5-15 \mathrm{~nm}$, colour: yellow-brown) (ITP., Poland) $(0.5 \%)$ (Table 1$)$. 
Table 1. Symbols and composition of individual samples

\begin{tabular}{|l|c|c|c|c|c|c|}
\hline \multirow{2}{*}{ Sample } & \multirow{2}{*}{ PE [\%] } & $\begin{array}{c}\text { Oxo-dedegradable concentrate } \\
\text { [\% mas.] }\end{array}$ & \multicolumn{3}{|c|}{$\begin{array}{c}\text { Etheral oils } \\
\text { [\% mas.] }\end{array}$} & $\begin{array}{c}\text { Mix. nanoAg } \\
\text { i nanoCu } \\
{[\% \text { mas.] }}\end{array}$ \\
\cline { 4 - 6 } & & - & geranium & clove & eucalyptus & - \\
\hline PE-0 & 100 & 1 & - & - & - & - \\
\hline PE-1A & 98 & 1 & - & 1 & - & - \\
\hline PE-2B & 98 & 1 & - & - & 1 & - \\
\hline PE-3C & 98 & 1 & - & - & - & - \\
\hline PE-4D & 98.5 & - & & - & - \\
\hline
\end{tabular}

The oxo-degradable concentrate - mixture of manganese and iron carboxylic salts (IMPiB OFiT, Gliwice) ${ }^{23}$. The percentage share of manganese $(\mathrm{Mn})$ and iron $(\mathrm{Fe})$ was respectively: $0.11-0.15 \% ; 0.9-1.0 \%$. A process for the preparation of the concentrate was the subject of patent ${ }^{23}$.

Films with a thickness ranging from 0.75 to $0.85 \mathrm{~mm}$ were made by extrusion blow moulding of low density polyethylene (PE-LD) on the Plasti-Corder PLV 151 Brabender. The films were extruded according the parameters: type of extruded product: from 0.75 to $0.85 \mathrm{~mm}$ thick film, melt temperature: $175-180^{\circ} \mathrm{C}$, temperature of cylinder areas: $165-190^{\circ} \mathrm{C}$, temperature of the head: $190^{\circ} \mathrm{C}$.

\section{Antibacterial properties}

The antibacterial properties of the materials obtained were evaluated acc. ISO 22196:2011: Measurement of antibacterial activity on plastic and non-porous surfaces. The analysis was carried out in three repetitions for each of the studied samples ${ }^{24}$.

Two bacterial strains were used in the studies: Staphylococcus aureus (ATCC 6538P) and Escherichia coli (ATCC 8739) (Argenta, Poznań). Bacterial strains were grown on Nutrient Agar medium containing $\left[\mathrm{g} / \mathrm{dm}^{3}\right]$ : meat extract -5.0 , peptone - 10.0, sodium chloride 5.0, agar -15.0 , distilled water $-1 \mathrm{dm}^{3}$ with $\mathrm{pH}$ 7.2.

Bacteria were incubated at $37^{\circ} \mathrm{C}$ for $24 \mathrm{~h}$. The obtained culture was collected with a sterile loop and bacterial inoculum was transferred to tubes containing Nutrient Broth (NB 1/500) $\left[\mathrm{g} / \mathrm{dm}^{3}\right]$ : meat extract -0.006 , pepton $-0.02, \mathrm{NaCl}-0.01$, distilled water $-1 \mathrm{dm}^{3}$ with $\mathrm{pH} 6.8$ 7.2. Thus obtained bacterial suspension was transferred to a densitometer (Densi-La-Meter ${ }^{\circledR} I I$, Lachema, Czech Republic) for the measurement of its optical density, subsequently brought to a value of 0.5 , which, according to Mc Farland standards, corresponds to $1.5 \times 10^{8}$ bacterial cells in $1 \mathrm{~cm}^{3}$. The suspension was then diluted with (NB 1/500) until the number of bacterial cells was 7.5 x $10^{5}$ in $1 \mathrm{~cm}^{3}$. The final suspensions were transferred to control film (PE-0) and test films (PE-1A, PE-2B, PE-3C, PE-4D) $(5 \times 5 \mathrm{~cm})$ and covered with sterile thin glass slides $(4 \times 4 \mathrm{~cm})$ in order to evenly distribute microorganisms on the surface. Previously samples were sterilized under UV light for 15 minutes using Sterilizer $\mathrm{NV}-208 \mathrm{~B}$. The samples were incubated for $24 \mathrm{~h}$ at $35^{\circ} \mathrm{C}$. After this time, viable bacterial cells were counted on the surface of the test and control samples. For this purpose, the films were rinsed with $10 \mathrm{~cm}^{3}$ SCDLP medium containing $\left[\mathrm{g} / \mathrm{dm}^{3}\right]$ : casein peptone -17.0 , soybean peptone - 3.0, sodium chloride - 5.0, disodium hydrogen phosphate -2.5 , glucose -1.0 , distilled water $-1 \mathrm{dm}^{3}$ with $\mathrm{pH}$ 6.8-7.2. Diluted suspension was inoculated on the PCA medium containing $\left[\mathrm{g} / \mathrm{dm}^{3}\right]$ : yeast agar -2.5 , tryptone -5.0 , glucose -1.0 , agar -15 , distilled water
- $1 \mathrm{dm}^{3}, \mathrm{pH} 7.0-7.2$. After 48-hour incubation at $35^{\circ} \mathrm{C}$, the number of grown colonies were converted to the numbers of bacterial cells.

Antibacterial activity $(\mathrm{R})$ was determined using the following equation:

$\mathrm{R}=(\mathrm{Ut}-\mathrm{Uo})-(\mathrm{At}-\mathrm{Uo})=\mathrm{Ut}-\mathrm{At}$

where:

$R\left(\log _{10}\right.$ reduction $)$ - difference between the logarithm of the average $c f u$ number (colony-forming unit) on reference samples after $24 \mathrm{~h}$, and the logarithm of the average $c f u$ on the test samples; $\mathrm{R}$ is antibacterial activity.

$U o-\log _{10}$ average of the number of living bacteria $\left(\right.$ cells $\left./ \mathrm{cm}^{2}\right)$ recovered from the reference sample immediately after inoculation $(0 \mathrm{~h})$.

$U t-\log _{10}$ average of the number of living bacteria $\left(\mathrm{cells} / \mathrm{cm}^{2}\right)$ recovered from the reference sample after $24 \mathrm{~h}$ from inoculation.

At $-\log _{10}$ average of the number of living bacteria (cells/cm2) recovered from the test sample after $24 \mathrm{~h}$ from inoculation.

\section{Water vapour permeability}

Determination of water vapour permeability $(\mathrm{Pv})$ was performed according to standard ISO 15106-1:2007, Plastics - Foils and boards. Determination of water vapor transmission rate - Part 1: Humidity sensor method using an L80-5000 device (PBI Dansensor) ${ }^{25}$. This test consisted in determining the amount of $[\mathrm{g}]$ of water vapour permeating the surface of a sample in a unit of time and at a constant temperature. Samples prepared for measurement were stabilized at $23 \pm 2^{\circ} \mathrm{C}$ and relative humidity of $50 \pm 5 \%$. Five measurements were taken for each sample and the arithmetic mean of these measurements was accepted as the result of the test. The test was carried out at $38^{\circ} \mathrm{C}$.

\section{RESULT AND DISCUSSION}

In accordance with ISO 22196:2011, packaging materials (including films) exhibit antibacterial properties if the reduction in the number of culturable test cells (R) between the control sample (e.g. film) and the test sample is at least 2 . The reduction $R \geq 2$ signifies a fall in the number of culturable bacteria by two orders of magnitude.

The results of the antibacterial / biostatic properties of the polyethylene oxide film with active additives are shown in Figure 1. An analysis of these results has revealed that the PE-3C film showed the weakest bacteriostatic properties with regard to $S$. aureus, while PE-2B film with regard to $S$. aureus. In turn, PE-1A showed antibacterial properties only against $S$. aureus. PE-4D material showed a reduction in the number of culturable E. coli and $S$. aureus cells by a magnitude of 


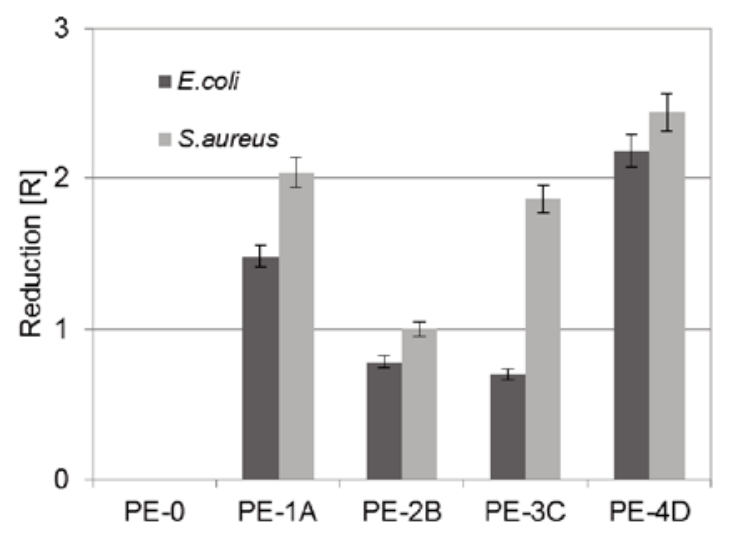

Figure 1. The test results determination antimicrobial properties of the films with respect to the strains of $E$. coli and $S$. aureus ( $\mathrm{R}$ - antibacterial activity). The data represented as $\pm \mathrm{SE}$ from triplicate experiments $(\mathrm{n}=3)$

more than 2. In light of the above, these samples are considered to possess antibacterial properties.

Taking into account all the results, it can be concluded that despite the failure of PE-2B and PE-3C samples to achieve $R \geq 2$ values, which would qualify them as antibacterial, they were nevertheless shown to possess bacteriostatic properties.

It has been shown that fatty and essential oils derived from spices and herbs, may constitute valuable film components $^{\mathbf{2 6}, 27,28}$. This is confirmed by other literature ${ }^{\mathbf{1 0}}$. According to the authors ${ }^{\mathbf{1 0}}$, oils derived from anise, lemon, geranium, clove, mint, rosemary, thyme and diluted in amounts of 1 part weight oil/10 part weight filler, demonstrated bacteriostatic and fungistatic properties. In addition, low density polyethylene (LDPE) with $1 \mathrm{wt} \%$ grapefruit seed extract effectively inhibited the growth of aerobic and coli bacteria in beef or lettuce packaging ${ }^{\mathbf{2 4}}$. According to publications ${ }^{\mathbf{1 8}}$, nanosilver introduced into the polyethylene matrix in an amount of $0.6 \%$ by weight effectively inhibited the growth of $E$. coli. Copper added in quantities up to $1 \%$ by weight into the polyethylene matrix gave it biostatic properties with regard to $S$. aureus bacteria in a range of $\mathrm{R}=0.04$ to $0.4^{\mathbf{2 0}}$.

The examples given show that the different antibacterial substances are used in amounts not exceeding $10 \mathrm{wt} \%$. How much is added depends on the nature of the substance and its properties.

The changes taking place in the tested films resulting from the influence of additives consisting of essential oils as well as nano silver and nano copper were also verified on the basis of changes in the films' functional properties, i.e. water vapour permeability (Pv) (Fig. 2).

Tests of the water vapour permeability of film samples containing the additives have revealed an increase in this parameter for most of the tested films. The most significant increase of Pv was noted for PE-2B and PE-D4 film and amounted to $112.3 \%$ and $116 \%$ respectively. In turn, the smallest increase in $\mathrm{Pv}(57.6 \%)$ was recorded for PE-1A film. Based on the test results it is concluded that changes in the water vapour permeability of oxodegradable films containing antibacterial substances consisted in a decrease of the films' barrier properties.

The permeability of water vapor through the test sample increased, so their barrier properties decreased.

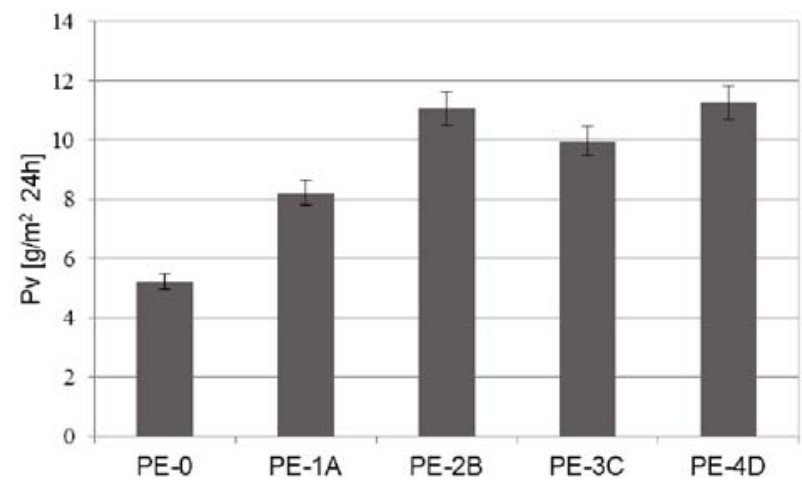

Figure 2. Water vapor permeability of the films tested. The data represented as \pm SE from quintuplicate experiments $(\mathrm{n}=5)$

The changes in film barrier are not a function. The reduction of film barrier is very important in the context of their use in the packaging. The additions in the form of nano $\mathrm{Ag} / \mathrm{Cu}$ and geranium, clove and eucalyptus oils have been selected by us for testing with a view to their application to films used in the food packaging industry. There are some potential limitations on eg. the nature of the food products. Choosing the films to the product takes into account the content of fats, carbohydrates or proteins. In addition, the state of aggregation, fragmentation and the character of packaged food are important. The individual characteristics of the packaged goods determine the type of packaging in which this product is to be found ${ }^{29,30,31}$.

Analyzing the results of our research should take into account the issue of the impact of oxo-degradable concentrate on the bactericidal properties and water vapor permeability.

It is worth considering how big the influence on the change of these parameters were the additives in the form of oils and nano $\mathrm{Ag} / \mathrm{Cu}$ mixture, and what oxidative concentrate that was present in each test sample except PE-0 reference sample. The effect of the oxo-degradable additive itself could be significant, since the pro-oxidants contain metal ions and can be expected to also have antimicrobial activity and effects on water vapor permeability. Therefore, taking this into account, further research should verify its independent role.

Richert et al. (2012) conducted functional tests, barrier polyethylene films with nanosilver in the amount of 0.2 , $0.4,0.6,0.8$ and $1.0 \%$ by mass. They showed that the permeability of water vapor for pure PE was higher than for other materials. They noted differences in water vapor permeability in the range from 4.6 to $18.8 \%$ depending on the used concentration of the nano addition in relation to the reference sample, which was $\mathrm{PE}^{\mathbf{2 1}}$.

There are many scientific and research works that show the results of water vapor permeability through films containing various additives. Unfortunately, comparing them with our results is quite difficult due to the differentness of both the polymer matrix used and the additives themselves, their form, as well as the concentrations $21,27,32$. 


\section{CONCLUSIONS}

The tests have shown that polyethylene (PE) can be modified by oils as well as silver and copper compounds. An additive consisting of a mixture of nanoAg and nanoCu effectively reduced the survival of $E$. coli and $S$. aureus bacteria and demonstrated antibacterial properties in PE-4K material. However, films containing geranium (PE-1A), clove (PE-2B) and eucalyptus (PE3C) oils showed bacteriostatic properties.

The additives led to changes in water vapour permeability, whereas the barrier properties of the films decreased with additive content in the polyethylene matrix. Oxo-degradable polyethylene films containing antibacterial substances are a very interesting group of materials with a wide range of applications in the packaging industry.

In further studies, the individual role of pro-oxidants should be considered. They can have an effect on the change of properties due to the presence of metal ions.

\section{ACKNOWLEDGEMENTS}

The study was part of the research project titled: "Oxo-degradable plastics with biocidal properties" (DS 210147) funded by a statutory subsidy of the Institute for Engineering of Polymer Materials and Dyes.

\section{LITERATURE CITED}

1. Khajehpour-Tadavani, S., Nejabat, G.R. \& Mortazavi, S.M.M. (2018). Oxo-biodegradability of high-density polyethylene films containing limited amount of isotactic polypropylene. J. Appl. Polym. Sci. DOI: 10.1002/app.45843.

2. Olewnik-Kruszkowska, E. Koter, I., Skopińska-Wiśniewska, J. \& Richert, J, (2015). Degradation of polylactide composites under UV irradiation at $254 \mathrm{~nm}$. J. Photochem. Photobiol. A: Chem. 311, 144-53. DOI: 10.1016/j.jphotochem.2015.06.029.

3. Olewnik, E., Garman, K., Piechota, G. \& Czerwiński, W. (2012). Thermal properties of nanocomposites based on polyethylene and n-heptaquinolinum modified montmorillonite. J. Therm. Anal. Calorim. 110, 479-484. DOI: 10.1007/ s10973-012-2380-9.

4. Shogren, R. (1997). Water vapor permeability of biodegradable polymers. J. Environ. Polym. Degrad. 2, 91-95. DOI: 10.1007/BF02763592.

5. Langer, E., Waśkiewicz, S., Lenartowicz-Klik, M. \& Bortel, K. (2015). Application of waste poly(ethylene terephthalate) in the syn-thesis of new oligomeric plasticizers. Polym. Degrad. Stabil. 119, 105-112. DOI: 10.1007/s13726-016-0502-0.

6. Mekonnen, T., Mussone, P., Khalil, H. \& Bressler, D. (2013). Progress in bio-based plastics and plasticizing modifications. J. Mater. Chem. A 1, 13379-13398. DOI: 10.1039/ c3ta12555f.

7. Waśkiewicz, S., Zenkner, K., Langer, E., Lenartowicz, M. \& Gajlewicz, I. (2013). Organic coatings based on new Schiff base epoxy resins. Prog. Org. Coat. 76, 1040-1045. DOI: 10.1016/j.porgcoat.2013.02.017.

8. Olewnik, E., Garman, K. \& Czerwiński, W. (2010). Thermal properties of new composites based on nanoclay, polyethylene and polypropylene. J. Therm. Anal. Calorim. 101, 323-329. DOI: 10.1007/s10973-010-0690-3.

9. Dehghani, S., ValiHosseini, S. \& Regenstein, J.M. (2018). Edible films and coatings in seafood preservation: A review. Food Chem. 240, 505-513. DOI: 10.1016/j.foodchem.2017.07.034.

10. Kmiotek, M., Bieliński, D.M., Piotrowska, M. \& Jakubowski, W. (2016). Essential oils as biocidal agents in natural rub- ber vulcanizates. Polimery 61, 39-45. DOI:dx.doi.org/10.14314/ polimery.2016.039 (in Polish).

11. Greenhalgh, R. \& Walker, J.T. (2017). Antimicrobial strategies for polymeric hygienic surfaces in healthcare. Int. Biodeter. Biodegr. 125, 214-227. DOI: 10.1016/j.ibiod.2017.09.009.

12. Chapi, S. \& Devendrappa, H. (2016). Structural, Optical and Thermal Study on PEO-Based Solid Polymer Electrolyte for Optical Device Applications. J. Mater. Sci. Mater. Electron. 27, 11974-11985. DOI: 10.1002/masy.201400272.

13. Ghafari, E., Ghahari, S.A. \& Feng, Y. (2016). Co-doping of magnesium with indium in nitrides: first principle calculation and experiment. Compos Part B-Eng. 105, 160-166. DOI: 10.1039/c5ra24642c.

14. Petchwattana, N., Covavisaruch, S. \& Wibooranawong, S. (2016). Antimicrobial food packaging prepared from poly (butylene succinate) and zinc oxide. Measurement 93, 442-448. DOI: 10.1016/j.measurement.2016.07.048.

15. Kawakami, H., Yoshida, K., Nishida, Y., Kikuchi, Y. \& Sato, Y. (2008). Antibacterial Properties of Metallic Elements for Alloying Evaluated with Application of JIS Z 2801:2000. ISIJ International 9, 1299-1304. DOI: 10.2355/isijinternational.48.1299.

16. Correa, E., Moncada, M.E. \& Zapata, V.H. (2017). Electrical characterization of an ionic conductivity polymer electrolyte based on polycaprolactone and silver nitrate for medical applications. Mater. Lett. 205, 155-157. DOI: 10.1016/j. matlet.2017.06.046.

17. Ghosh, A., Maity, A., Banerjee, R. \& Majumder, S.B. (2017). Volatile organic compound sensing using copper oxide thin films: Addressing the cross sensitivity issue. J. Alloy. Compd. 692, 108-118. DOI: 10.1016/j.jallcom.2016.09.001.

18. Żenkiewicz, M., Richert, J., Rytlewski, P. \& Richert, A. (2011). Comparative analysis of shungite and graphite effects on some properties of polylactide composites. Polym. Test. 30, 429-435. DOI: 10.1016/j.polymertesting.2011.03.004.

19. Walczak, M., Richert, A. \& Burkowsk-But, A. (2014). The effect of polyhexamethylene guanidine hydrochloride (PHMG) derivatives introduced into polylactide (PLA) on the activity of bacterial enzymes. J. Ind. Microbiol. Biotechnol. 41, 1719-1724. DOI: 10.1007/s10295-014-1505-5.

20. Świontek Brzezińska, M., Walczak, M., Richert, A., Kalwasinska, A. \& Pejchalová, M. (2016). The Influence of Polyhexamethylene Guanidine Derivatives Introduced into Polyhydroxybutyrate on Biofilm Formation and the Activity of Bacterial Enzymes. Appl. Biochem. Microbiol. 3, 298-303. DOI:10.1134/S0003683816030170.

21. Richert, A. (2017). Structural and barrier properties of polylactide films with bacteriocins after biodegradation in a compost extract. Przem. Chem. 96/6, 1313-1316. DOI: 10.15199/62.2017.6.18 (in Polish).

22. Siegel, J., Polívková, M., Staszek, M., Kolářová, K., Rimpelová, S. \& Švorčík, V. (2015). Nanostructured silver coatings on polyimide and their antibacterial response. Mater. Lett. 145, 87-90. DOI: 10.1016/j.matlet.2015.01.050.

23. Cichy, B., Kużdżał, E., Turkowska, M., Kwiecień, J., Rymarz, G., Gibas, E., Kubica, S., Swinarew, B., Kowalska, B., Hexel, L., Soja, M. (2017). A catalyst for the degradation of thermoplastics and the method of its production. Patent P.395713 (in Polish).

24. International Standard (2011). Measurement of antibacterial activity on plastic and non-porous surfaces. ISO 22196.

25. International Standard (2007). Plastics. Foils and plates. Determination of water vapor transmission rate. Part 1: Humidity sensor method. ISO 15106.

26. Ouattara, B., Simard, R.E., Holley, R.A., Piette, G.J.P. \& Begin, A. (1997). Antibacterial activity of selected fatty acids and essential oils against six meat spoilage organisms. Int. J. Food Microbiol. 37, 155-162. DOI: 10.1016/S0168-1605(97)00070-6. 
27. Wang, L. \& Johnson, E.A. (1992). Inhibition of Listeria monocytogenes by fatty acids and monoglycerides. Appl. Environ. Microbiol. 58, 624-629.

28. Tan, O., Sumińska, P. \& Bartkowiak, A. (2015). Antimicrobial activity of cinnamon oil and chinese argy wormwood oil, as components of active film-forming emulsions for coating of cellulosic packaging materials. Opakowanie 5, 57-61 (in Polish).

29. Sip, A. \& Jusik, P. (2008). Bacteriocins as packaging constituents with antimicrobial action. Opakowanie 10, 20-26 (in Polish).

30. Sip, A. \& Jusik, P. (2009). Introducing of antimicrobial substances into packaging materials. Opakowanie 1, 42-47 (in Polish).

31. Siracusa, V., Rocculi, P., Romani, S. \& Dalla Rosa, M. (2008), Biodegradable polymers for food packaging: a review. Trends Food Sci. Technol. 19, 634-643. DOI: 10.1016/j. tifs.2008.07.003.

32. Richert, J., Richert, A. \& Żenkiewicz, M. (2012). Effect of silver nanoparticles on some physic-chemical and biological properties of polyethylene-matrix nanocomposites. Przem. Chem. 91/8, 1613-1616 (in Polish). 